$\begin{array}{ll}\text { Volume } & : 05 \\ \text { Nomor } & : 01 \\ \text { Bulan } & : \text { Januari } \\ \text { Tahun } & : 2019 \\ \text { http } & : / / \text { jurnal.pps.ung.ac.id/index.php/AKSARA/index }\end{array}$

\title{
PENGARUH MODEL PROBLEM BASED LEARNING TERHADAP HASIL BELAJAR
}

\author{
Triono Djonomiarjo \\ Guru SMK Negeri 1 Patilanggio Kab. Pohuwato \\ triyono@gmail.cm
}

Received: 25 November 2018; Revised: 1 Desember 2018; Accepted: 5 Desember 2018

\begin{abstract}
ABSTRAK
Hasil belajar siswa merupakan output dari proses belajar mengajar. Salah satu masalah dalam pembelajaran di sekolah adalah rendahnya hasil belajar siswa. Hal ini dapat diketahui dari data awal nilai ulangan harian siswa yang masih berada di bawah KKM. Banyak faktor-faktor yang mempengaruhi hasil belajar salah satunya adalah model pembelajaran. Model Pembelajaran Problem Based Learning merupakan model pembelajaran kooperatif yang menuntut siswa untuk aktif dan memotivasi siswa supaya dapat saling mendukung dan membantu satu sama lain dalam menguasi materi pelajaran yang dipelajari. Setelah penelitian dilakukan ternyata hasil belajar pada kelas yang menggunakan model pembelajaran PBL 81,14 lebih tinggi dari pada kelas yang menggunakan model pembelajaran Konvensional 76,98. Berdasarkan uji statistik diperoleh $t_{\text {hitung }} 2,4046$ dan $t_{\text {tabel }} 1,9893$. Karena nilai $t_{\text {hitung }}>t_{\text {tabel }}(2,4046>1,9893)$ berarti maka dapat disimpulkan bahwa $\mathrm{H}_{\mathrm{o}}$ ditolak dan $\mathrm{H}_{\mathrm{a}}$ diterima. Dari analisis yang telah dilakukan dapat disimpulkan bahwa terdapat perbedaan yang signifikan antara hasil belajar IPS Ekonomi yang menggunakan model pembelajaran PBL dengan model pembelajaran Konvensional pada siswa kelas X SMK Negeri 1 Patilanggio.
\end{abstract}

Kata Kunci: Hasil Belajar, Model Pembelajaran Problem Based Learning.

\section{PENDAHULUAN}

Pendidikan merupakan salah satu faktor yang memerlukan perhatian tersendiri dalam pembagunan nasional yaitu usaha mencerdaskan kehidupan bangsa, karena dengan pendidikan akan meningkatkan kualitas sumber daya manusia yang dijadikan modal utama pelaksanaan pembagunan. Pendidikan yang mampu mendukung pembagunan di masa mendatang adalah pendidikan yang mampu memiliki dan memecahkan problem pendidikan yang dihadapinya. Pendidikan harus menyentuh potensi nurani maupun potensi kompetensi peserta didik. Konsep pendidikan tersebut terasa semakin penting ketika seorang harus memasuki kehidupan dimasyarakat dan dunia kerja, karena yang bersangkutan harus mampu menerapkan apa yang dipelajari di sekolah untuk menghadapi problem yang dihadapi dalam kehidupan sehari-hari saat ini maupun yang akan datang.

Sekolah sebagai suatu instansi atau lembaga pendidikan idealnya harus mampu melakukan proses edukasi, sosialisasi, dan transformasi. Dengan kata lain, sekolah yang bermutu adalah sekolah yang mampu berperan sebagai proses edukasi (proses pendidikan yang menekankan pada kegiatan mendidik dan mengajar), proses sosialisasi (proses bermasyarakat terutama bagi anak didik), dan waddah proses transformasi ( proses perubahan tingkah laku ke arah yang lebih baik atau lebih maju). 


$\begin{array}{ll}\text { Volume } & : 05 \\ \text { Nomor } & : 01 \\ \text { Bulan } & : \text { Januari } \\ \text { Tahun } & : 2019 \\ \text { http } & : / / \text { ejurnal.pps.ung.ac.id/index.php/AKSARA/index }\end{array}$

Dalam proses belajar mengajar guru merupakan faktor utama dan kinerja guru dalam proses belajar mengajar adalah parameter utama kualitas pendidikan. Guru adalah faktor penentu kualitas pendidikan karena gurulah yang berhadapan langsung dengan peserta didik. Pembelajaran pada dasarnya adalah proses interaksi anatar peserta didik dengan lingkungannya, sehingga terjadi perubahan perilaku ke arah yang lebih baik selain itu juga tujuan umum dari pembelajaran IPS Ekonomi adalah untuk mengembangkan kemampuan siswa dalam mengaplikasikan dalam kehidupan seharihari. Dalam proses pembelajaran guru perlu meningkatkan kemampuan mengajar sehingga siswa dapat maksimal walaupun dalam kenyataanya guru-guru di Indonesia sebagian besar masih mempertahan kan model-model pembelajaran lama.

Strategi pembelajaran adalah salah satu faktor yang dapat mempengaruhi tujuan pemnbelajaran jika penggunaannya tidak tepat maka dapat menghambat tujuan pembelajaran tersebut. Untuk melaksanakan suatu strategi pembelajaran digunakan model mengajar. Penggunaan model mengajar dapat membantu guru dalam mengaktifkan proses belajar mengajar dikelas. Menurut Fathurrohman (dalam Hamruni, 2012:7) model mengajar adalah cara-cara menyajikan bahan pelajaran kepada peserta didik untuk tercapainya tujuan yang telah ditetapkan.

Kemampuan guru sebagai salah satu usaha meningkatkan mutu pendidikan di sekolah dimana guru merupakan elemen di sekolah yang secara langsung dan aktif bersinggungan dengan siswa, kemampuan yang dimaksud adalah kemampuan mengajar dengan menerapkan model pembelajaran yang tepat, efesien dan efektif. Pendekatan teacher centered sudah dianggap tradisional dan perlu diubah ini karena pendekatan teacher centered, dimana pembelajaran berpusat pada pendidikan dengan penekanan pada peliputan dan penyebaran materi, sementara siswa kurang aktif, sudah tidak memadai untuk tuntunan era pengetahuan.

Berdasarkan observasi awal dan wawancara yang dilakukan penulis dengan guru bidang studi IPS Ekonomi di SMK Negeri 1 Patilanggio pada hari senin tanggal 20 November 2017 diperoleh informasi bahwa model problem based learning belum pernah digunakan dalam proses pembelajaran. Selama ini pembelajaran IPS Ekonomi di kelas X SMK Negeri 1 Patilanggio masih menerapkan model pembelajaran ceramah-resitasi. Begitu masuk kelas, guru memberikan ceramah tentang materi pelajaran yang telah dicatat sebelumnya, kemudian dilanjutkan dengan memberi siswanya beberapa latihan soal atau tugas. Siswa diminta untuk membuka buku catatan dan mengerjakan buku lembar kerja atau menjawab pertanyaan yang diajukan oleh guru. Proses pembelajaran dengan model konvensional ceramah masih belum cukup memberikan kesan yang mendalam pada siswa, karena peran guru dalam menyampaikan materi lebih dominan dibandingkan keaktifan siswa sendiri. Guru lebih banyak memberikan penjelasan dari pada memperhatian respon siswa terhadap materi yag disampaikan. Oleh sebab itu, guru harus mempunyai kreativitas tinggi dalam memilih model pembelajaran.

Sesuai hasil observasi, pembelajaran IPS Ekonomi di SMK Negeri 1 Patilanggio belum mencapai tingkat keberhasilan yang diinginkan. Hal ini dapat dilihat dari nilai rata-rata hasil belajar siswa kelas $\mathrm{X}$ semester Genap seperti pada tabel berikut : 
Tabel. 1.1 Nilai Rata-Rata Hasil Belajar Siswa Kelas X Semester Genap SMK Negeri 1 Patilanggio

\begin{tabular}{|c|c|c|}
\hline Kelas & Nilai Rata-Rata Kelas & KKM \\
\hline X ATPH & 65,04 & 70 \\
\hline X AP & 66,90 & 70 \\
\hline X MP & 60,20 & 70 \\
\hline
\end{tabular}

\section{Sumber : Data dari guru mata pelajaran IPS Ekonomi TA 2017/2018}

Rendahnya hasil belajar siswa pada mata pelajaran IPS Ekonomi merupakan salah satu masalah yang ingin guru perbaiki, untuk itu dibutuhkannya model pembelajaran terhadap pelajaran IPS Ekonomi agar meningkatkan hasil belajar siswa. Menurut Djemari Mardapi (2008:102) hasil belajar ditentukan oleh kualitas proses pembelajaran karena hasil belajar merupakan suatu kemampuan atau keterampilan yang dimiliki oleh siswa tersebut mengalami aktivitas belajar.

Dengan membiarkan siswa pasif, pendekatan yang berpusat pada pendidik sulit meningkatkan siswa mengembangkan kecakapan berfikir, kecakapan interpersonal, kecakapan beradaptasi dengan baik tidak banyak yang mereka dapatkan bila partisipasi mereka minim dalam proses pembelajaran. Padahal berbagai kecakapan ilmiah yang nantinya mereka butuhkan saat menjalani kehidupan dewasa mereka. Interaksi guru dengan siswa sangat dibutuhkan, dengan interaksi tersebut diharapkan siswa dapat membangun jati diri (learning to be). Untuk mencapai tujuan pendidikan dan kemampuan zaman yang menuntut siswa untuk memiliki kecakapan berfikir, kecakapan interpesonal, kecakapan beradaptasi dengan baik, kecakapan ilmiah yang nantinya diperlukan dalam dunia kerja maka dibutuhkan model pengajaran yang sesuai salah satunya adalah model problem based learning (PBL). Menurut Duch, Allen dan White dalam Hamruni (2012:104) model problem based learning menyediakan kondisi untuk meningkatkan keterampilan berfikir kritis dan analitis serta memecahkan masalah kompleks dalam kehidupan nyata sehingga akan memunculkan "budaya berfikir" pada diri siswa, proses pembelajaran yang seperti ini menuntut siswa untuk berperan aktif dalam kegiatan pembelajaran yang tidak hanya berpusat pada guru dengan begitu dapat meningkatkan hasil belajar siswa pada materi pelajaran yang disampaikan.

Pendekatan pemecahan masalah ini menempatkan guru sebagai fasilisator dimana kegiatan belajar mengajar akan dititik beratkan pada keafektifan siswa. Proses pembelajaran yang mengikut sertakan siswa secara aktif baik individu maupun kelompok, akan lebih bermakna karena dalam proses pembelajaran siswa mempunyai lebih banyak pengalaman.

Untuk tertib diri belajar sendiri harus dengan prinsip-prinsip. Salah satu prinsip yang harus dikerjakan yaitu "belajar harus dengan minat". Banyak para siswa didalam belajarnya nampak tidak tahu atau kurang adanya minat dan belum ada niat untuk 


$\begin{array}{ll}\text { Volume } & : 05 \\ \text { Nomor } & : 01 \\ \text { Bulan } & : \text { Januari } \\ \text { Tahun } & : 2019 \\ \text { http } & : / / \text { jurnal.pps.ung.ac.id/index.php/AKSARA/index }\end{array}$

berusaha bagaimana ia dapat menumbuhkan minatnya di dalam belajar, mereka selalu merasakan belajar adalah beban. Unsur minat bepengaruh terhadap kualitas belajar seorang, siswa yang berminat terhadap suatu pelajaran akan mempelajari dengan sungguh-sungguh sebab daya tarik baginya.

\section{TINJAUAN PUSTAKA}

\section{Pengertian Belajar}

Menurut Gagne (dalam Dimyati dan Mujiono, 2009:10) belajar merupakan kegiatan yang kompleks, setelah belajar orang memiliki keterampilan, pengetahuan, sikap dan nilai. Timbulnya kapabilitas tersebut dari (i) stimulasi yang berasal dari lingkungan dan (ii) proses kognitif yang dilakukan oleh pembelajar. Jadi belajar merupakan seperangkat proses kognitif yang mengubah sifat stimulasi lingkungan, melewati pengolahan informasi menjadi kapabilitas baru.

\section{Pengertian Hasil Belajar}

Menurut Oemar Hamalik (2011:30) hasil belajar adalah bila seseorang telah belajar akan terjadi perubahan tingkah laku pada orang tersebut, misalnya dari tidak tahu menjadi tahu, dan dari tidak mengerti menjadi mengerti. Hasil belajar menurut Sudjana (1990:22) adalah kemampuan yang dimiliki siswa setelah ia menerima pengalaman belajarnya. Jadi hasil belajar merupakan suatu kemampuan atau keterampilan yang dimiliki oleh siswa setelah siswa tersebut mengalami aktivitas belajar.

\section{Model Pembelajaran Problem Based Learning ( PBL )}

Keberhasilan proses belajar mengajar salah satunya ditentukan oleh model mengajar yaitu bagaimana cara guru menyampaikan materi yang akan diajarkan. Secara harfiah metode (method) berarti "cara". Dalam pemakaian yang umum, model diartikan sebagai cara melakukan sesuatu kegiatan atau cara melakukan pekerjaan dengan menggunakan fakta dan konsep-konsep secara sistematis. Hamruni (2012:7) mengemukakan model mengajar adalah cara-cara menyajikan bahan pelajaran pada peserta didik untuk tercapainya tujuan yang telah ditetapkan. Sedangkan model pembelajaran pada dasarnya merupakan bentuk pembelajaran yang tergambar dari awal sampai akhir yang disajikan secara khas oleh guru. Dengan kata lain, model pembelajaran merupakan bungkus atau bingkai dari penerapan suatu pendekatan, metode, dan tehnik pembelajaran. Sukamto dalam (Trianto, 2007:5) mengemukakan maksud dari model pembelajaran adalah kerangka konseptual yang melukiskan prosedur yang sistematis untuk mencapai tujuan belajar tetentu dan berfungsi sebagai pedoman bagi para perancang pembelajaran dan para pengajar dalam merencanakan aktivitas belajar mengajar. Oleh karena salah satu hal yang sangat mendasar untuk dipahami guru adalah bagaimana memahami kedudukan model sebagai salah satu komponen dalam pendidikan yang dapat menciptakan pembelajaran yang efektif sesuai dengan pendapat Djamarah dan Zain (2006:74) yang mengatakan model adalah strategi pengajaran yang dapat mencapai tujuan yang diharapkan.

\section{Metode Pembelajaran Konvensional (Ceramah)}

Menurut Nasution (1986:18) pendekatan secara konvensional adalah dimana guru menyampaikanbahan pelajaran kepada murid. Jadi guru merupakan sumber belajar 


$\begin{array}{ll}\text { Volume } & : 05 \\ \text { Nomor } & : 01 \\ \text { Bulan } & : \text { Januari } \\ \text { Tahun } & : 2019 \\ \text { http } & : \text { //ejurnal.pps.ung.ac.id/index.php/AKSARA/index }\end{array}$

satu-satunya bagi siswa. Pembelajaran dengan pendekatan konvensional telah lama dilaksanakan dalam proses belajar mengajar sehingga pendekatan ini sering disebut dengan pembelajaran model ceramah. Menurut Djamarah dan Zain (2006:97) model ceramah adalah cara penyajian pelajaran yang dilakukan guru dengan peraturan atau penjelasan secara langsung terhadap siswa sedangkan menurut Rostiyah (1986:68) model ceramah adalah cara mengajar dengan menuturkan materi saja, tanpa memperhatikan bagaimana respon siswa terhadap apa yang disampaikannya, walaupun guru memberikan kesempatan kepada siswa, siswa tidak mau bertanya walaupun mereka belum memahami materi pelajaran yang disampaikan oleh guru tersebut.

\section{Hakikat IPS Ekonomi}

Ilmu IPS Ekonomi merupakan cabang ilmu sosial yang mempelajari berbagai perilaku pelaku IPS Ekonomi terhadap keputusan-keputusan IPS Ekonomi yang dibuat. Ilmu ini diperlukan sebagai kerangka berpikir untuk dapat melakukan pilihan terhadap berbagai sumber daya yang terbatas untuk memenuhi kebutuhan manusia yang tidak terbatas.

Pokok masalah IPS Ekonomi ada tiga, yaitu: produksi, konsumsi dan distribusi. Produksi, menyangkut masalah usaha atau kegiatan mencipta atau menambah kegunaan suatu benda. Konsumsi, menyangkut kegiatan menghabiskan atau mengurangi kegunaan suatu benda.

\section{METODE PENELITIAN}

Penelitian ini termasuk dalam penelitian eksperimen semu (quasi experimen). Menurut Sugiyono (2013:77), bentuk desain eksperimen ini merupakan pengembangan dari true experimental design, yang sulit dilaksanakan. Desain ini mempunyai kelompok kontrol, tetapi tidak dapat berfungsi sepenuhnya untuk mengontrol variabel-variabel luar yang mempengaruhi pelaksanaan eksperimen. Desain ini digunakan pada kenyataannya sulit mendapatkan kelompok kontrol yang digunakan untuk penelitian.

Penelitian ini banyak digunakan dalam bidang ilmu pendidikan dan ini menggunakan siswa kelas X. Penelitian ini melakukan perlakuan yang berbeda pada dua kelas, kelas yang satu sebagai kelas ekperimen dan kelas yang satunya sebagai kelas kontrol. Dalam penelitian ini penelitian dilakukan sebanyak dua kali yaitu sebelum eksperimen dan sesudah eksperimen. Penilaian sebelum eksperimen disebut pretest dan penilaian sesudah eksperimen adalah posttest.

\section{HASIL PENELITIAN DAN PEMBAHASAN}

Setelah dilakukan penelitian tentang Pengaruh Model Problem Based Learning (PBL) Terhadap Hasil Belajar IPS Ekonomi Kelas X SMK Negeri 1 Patilanggio diperoleh hasil yang meliputi deskripsi data, analisis data dan pembahasan.

Penelitian ini bertujuan untuk mengetahui apakah terdapat perbedaan hasil belajar IPS Ekonomi yang signifikan antara yang menggunakan model pembelajaran PBL dengan model pembelajaran Konvensional pada siswa kelas X IPS SMK Negeri 1 Patilanggio. Hasil penelitian melalui tes akhir pilihan ganda dengan 5 pilihan jawaban ( $a, b, c, d$, dan e) dari 35 butir soal yang direncanakan, setelah diuji cobakan ternyata 


$\begin{array}{ll}\text { Volume } & : 05 \\ \text { Nomor } & : 01 \\ \text { Bulan } & : \text { Januari } \\ \text { Tahun } & : 2019 \\ \text { http } & : / / \text { ejurnal.pps.ung.ac.id/index.php/AKSARA/index }\end{array}$

setelah dianalisis dari 35 soal hanya 30 soal yang bisa dipakai kemudian dilakukan untuk menguji kemampuan pada kedua subjek penelitian.

Hasil analisis awal pada saat pelaksanaan pretest, kedua kelas penelitian belum mendapatkan materi pembelajaran sehingga belum ada siswa yang berhasil mencapai KKM. Dari data pretest menunjukkan bahwa pada kelompok yang

menggunakan model pembelajaran PBL memperoleh jumlah skor total adalah 1965 dengan mean ( ${ }^{-}$) adalah 46,79, dengan simpangan baku (S) 10,66, sedangkan untuk data pretest pada kelompok yang menggunakan model Konvensional memperoleh jumlah skor total adalah 1987, dengan mean( ${ }^{-}$) 47,31 dengan simpangan baku (S) 10,52. Hal ini membuktikan bahwa kemampuan awal siswa adalah sama dan siap untuk mendapatkan perlakuan.

Setelah diketahui kelompok tersebut berangkat dari kondisi awal yang sama, kemudian kedua kelompok diberi perlakuan yang berbeda, pada kelas eksperimen I menggunakan model pembelajaran PBL dan kelas eksperimen II menggunakan model pembelajaran Konvensional. Setelah pembelajaran pada kelas eksperimen I dan eksperimen II selesai, dilanjutkan dengan pemberian posttest pada kedua kelas. Dari hasil posttest antara kedua kelas menunjukan hasil yang berbeda antar kedua kelas tersebut data posttest pada kelompok model pembelajaran PBL memperoleh jumlah skor total adalah 3233 dengan mean ( ${ }^{-}$) adalah 76,98 dan simpangan baku (S) adalah 7,74. Sedangkan untuk data post test pada kelompok yang menggunakan model pembelajaran Konvensional memperoleh jumlah skor total adalah 3408, dengan mean (') 81,14, dengan simpangan baku (S) adalah 8,11.

Hasil ini menunjukkan adanya temuan penelitian bahwa terdapat perbedaan ratarata hasil belajar (posttest) yang signifikan antar kedua kelas, dimana rata-rata nilai hasil belajar kelas eksperimen II lebih tinggi dari pada rata-rata nilai hasil belajar kelas eksperimen I. Nilai rata-rata posttest pada kelas eksperimen II sebesar 81,14 lebih tinggi dibandingkan kelas eksperimen I sebesar 76,98. Artinya kelas dengan menggunakan model pembelajaran PBL lebih efektif meningkatkan hasil belajar siswa dibandingkan dengan model pembelajaran Konvensional yang telah teruji oleh data. Dapat dikatakan bahwa perbedaan hasil belajar dari kedua kelas ini merupakan efek dari perlakuan.

Berdasarkan uraian tersebut, dan dibuktikan dengan uji hipotesis pada posttest didapat nilai $t_{\text {hitung }}>t_{\text {tabel }}(2,384>1,9893)$, membuktikan bahwa $\mathrm{H}_{\mathrm{a}}$ diterima yaitu Terdapat perbedaan hasil belajar IPS Ekonomi yang signifikan antara yang menggunakan model pembelajaran PBL dengan model pembelajaran Konvensional pada siswa kelas X SMK Negeri 1 Patilanggio.

Menurut Slavin (2015:14) PBL memiliki banyak kesamaan dinamika dengan Konvensional, tetapi menambahkan dimensi kegembiraan yang diperoleh dari penggunaan permainan. Teman satu tim akan saling membantu dalam mempersiapkan diri untuk permainan dengan mempelajari lembar kegiatan dan menjelaskan masalahmasalah satu sama lain, tetapi sewaktu siswa sedang bermain dalam game temannya tidak boleh membantu, memastikan telah terjadi tanggung jawab individual. Materi yang sama yang digunakan dalam PBL dapat juga digunakan dalam Konvensional, kuis PBL digunakan sebagai game dalam PBL. Sebagian guru lebih memilih PBL karena faktor menyenangkan dan kegiatannya, sementara yang lain lebih memilih yang murni yang bersifat kooperatif saja yaitu PBL, dan banyak juga yang mengkombinasikan keduanya. 


$\begin{array}{ll}\text { Volume } & : 05 \\ \text { Nomor } & : 01 \\ \text { Bulan } & : \text { Januari } \\ \text { Tahun } & : 2019 \\ \text { http } & : \text { //ejurnal.pps.ung.ac.id/index.php/AKSARA/index }\end{array}$

Berdasarkan penjelasan di atas, bahwa dengan pemberian model pembelajaran yang tepat dalam proses belajar mengajar sangat berpengaruh terhadap penigkatan kegiatan dan hasil belajar siswa. Semua guru menginginkan supaya dalam kegiatan belajar mengajar sesuai dengan harapan dan keinginan yang dicapai setelah proses belajar mengajar berakhir. Agar apa yang diharapkan dapat berhasil maka dengan demikian perlu adanya perubahan-perubahan dalam proses pembelajaran sehingga pengajaran mempunyai mutu yang baik.

\section{PENUTUP}

Berdasarkan hasil penelitian dan pembahasan yang diuraikan pada bab sebelumnya, didapat nilai $t_{\text {hitung }}>t_{\text {tabel }}$ atau( $\left.2,384>1,9893\right)$. Dengan demikian dapat disimpulkan bahwa terdapat perbedaan hasil belajar IPS Ekonomi yang signifikan antara yang menggunakan model pembelajaranProblem Based Learning (PBL) dengan model pembelajaran Konvensional (Ceramah) pada siswa kelas X SMK Negeri 1 Patilanggio. Dimana rata-rata nilai hasil belajar kelas kontrol lebih tinggi daripada rata-rata nilai hasil belajar kelas eksperimen . Nilai rata-rata posttest pada kelas kontrol sebesar 81,14 dan kelaseksperimen sebesar 76,98. Artinya kelas dengan menggunakan model pembelajaran PBL lebih efektif meningkatkan hasil belajar siswa dibandingkan dengan model pembelajaran Konvensional.

Berdasarkan hasil penelitian ini maka penulis menyarankan sebagai berikut:

1. Kepada guru, terutama guru Mata Pelajaran IPS Ekonomi sebaiknya dalam melakukan pengajaran dengan model pembelajaran yang bervariasi seperti model pembelajaran Problem Based Learning (PBL) dan Konvensional (Ceramah). Jangan hanya terpaku dengan gaya menjelaskan, berceramah dan membaca buku yang secara tidak langsung membuat siswa menjadi tidak dalam kegiatan belajar. Banyak cara sederhana yang digunakan dalam meningkatkan hasil belajar siswa dalam menumbuhkan semangat siswa diantaranya dengan menggunakan model pembelajaran Problem Based Learning PBL dan Konvensional Ceramah.

2. Bagi sekolah, dapat memberikan manfaat untuk menambah khasanah ilmu pengetahuan, wawasan, khasanah kajian pustaka mengenai model pembelajaran Problem Based Learning (PBL) dan Konvensional (Ceramah) untuk meningkatkan hasil belajar siswa.

\section{DAFTAR PUSTAKA}

Arikunto, S. 2010. Manajemen Penelitian, Jakarta : Rhineka Cipta

Arleli, 2012. Meningkatkan minat belajar pada pembelajaran IPS IPS Ekonomi Model berfikir kreatif (creative Thinking model)

Asep J, dan Abdul H, 2012. Evaluasi pembelajaran. Yogyakarta : Multi Persindo

Ary, Donald dkk. Pengantar penelitian dalam pendidikan terjemahan Arief Furchman. 2011. Yogyakarta : Pustaka Pelajar

Djamarah, S, B dan Zain, A. 2006. Strategi belajar mengajar. Jakarta : Rhineka Cipta

Dimyati, dan Mujiono. 2009. Belajar dan pembelajaran. Jakarta : Rhineka Cipta 


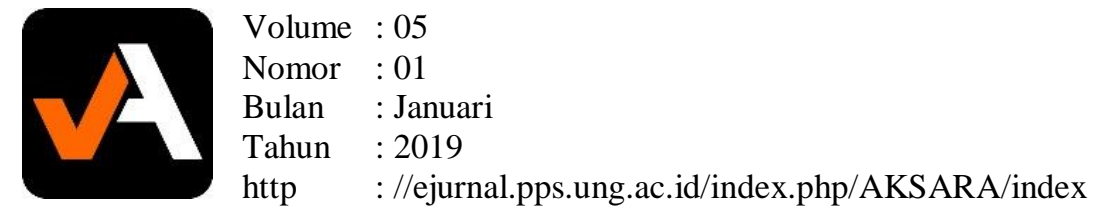

Hamruni, 2012. Strategi pembelajaran. Yogyakarta : Insan Madani

Huda, Miftahul. 2014. Model-model pengajaran dan pembelajaran. Yogyakarta : Pustaka Pelajar.

Kiptiyah, M. 2006. Persepsi siswa tentang bimbingan belajar dan minat belajar serta hubungannya dengan hasil belajar IPS Ekonomi, skripsi. Universitas Jambi. Jambi

Neolaka, Amos. 2014. Metode penelitian dan statistik. Bandung : PT Remaja Rosda Karya. Offset.

Rusman, 2011. Model-model pembelajaran mengembangkan professionalisme Guru. Jakarta : Rajawali

Sastrawati, E. 2011. Pengaruh media pembelajaran problem based learning dan startegi metakognitis terhadap keterampilan berfikir tingkat tinggi pada mata pelajaran matematika sekolah menegah pertama. Tidak dipublikasikan

Slameto, 2010. Belajar dan faktor-faktor yang mempengaruhi. Jakarta : Rhineka Cipta

Sudjana. 2005. Metode statistika. Bandung : PT Tarsito Bandung.

Sugiyono. 2014. Metode penelitian pendidikan (pendekatan kauntitatif, kualitatif, dan R \& D). Bandung : Alfabeta

Wena, K. 2009. Strategi pembelajaran inovatif kontemporer. Jakarta : Bumi Aksara 